\title{
Plaque-left-behind after brushing: intra-oral reservoir for antibacterial toothpaste ingredients
}

\author{
Marieke P. T. Otten • Henk J. Busscher • Frank Abbas • \\ Henny C. van der Mei • Chris G. van Hoogmoed
}

Received: 10 January 2011 / Accepted: 18 November 2011 /Published online: 13 December 2011

(C) The Author(s) 2011. This article is published with open access at Springerlink.com

\begin{abstract}
Objectives Plaque is never fully removed by brushing and may act as a reservoir for antibacterial ingredients, contributing to their substantive action. This study investigates the contribution of plaque-left-behind and saliva towards substantivity of three antibacterial toothpastes versus a control paste without antibacterial claims.

Materials and methods First, volunteers brushed 2 weeks with a control or antibacterial toothpaste. Next, plaque and saliva samples were collected 6 and $12 \mathrm{~h}$ after brushing and bacterial concentrations and viabilities were measured. The contributions of plaque and saliva towards substantivity were determined by combining control plaques with experimental plaque or saliva samples and subsequently assessing their viabilities. Bacterial compositions in the various plaque and saliva samples were compared using denaturing gradient gel electrophoresis.

Results The viabilities of plaques after brushing with Colgate-Total ${ }^{\circledR}$ and Crest-Pro-Health ${ }^{\circledR}$ were smaller than of control plaques and up to $12 \mathrm{~h}$ after brushing with Crest-Pro-Health ${ }^{\circledR}$ plaques still contained effective, residual antibacterial activity against control plaques. No effective,
\end{abstract}

M. P. T. Otten • H. J. Busscher • H. C. van der Mei •

C. G. van Hoogmoed $(\bowtie)$

Department of Biomedical Engineering, University Medical

Center Groningen and University of Groningen,

A. Deusinglaan 1,

9713 AV Groningen, The Netherlands

e-mail: C.G.van.Hoogmoed@umcg.nl

F. Abbas

Center for Dentistry and Oral Hygiene, University Medical Center

Groningen and University of Groningen,

Groningen, The Netherlands residual antibacterial activity could be measured in saliva samples after brushing. There was no significant difference in bacterial composition of plaque or saliva after brushing with the different toothpastes.

Conclusions Plaque-left-behind after mechanical cleaning contributes to the substantive action of an antibacterial toothpaste containing stannous fluoride (Crest-Pro-Health ${ }^{\circledR}$ ).

Clinical relevance The absorptive capacity of plaque-leftbehind after brushing is of utmost clinical importance, since plaque is predominantly left behind in places where its removal and effective killing matter most. Therewith this study demonstrates a clear and new beneficial effect of the use of antibacterial toothpastes.

Keywords Substantivity · Oral antibacterials · Toothpastes . Plaque $\cdot$ Saliva

\section{Introduction}

In the prevention of oral diseases, adequate oral home care is essential and the most applied method to attain this goal is the removal of dental plaque. Although mechanical removal usually yields over $80 \%$ removal, plaque is inevitably left behind in the majority of people [1]. Moreover, a plaque score of 0 can never be achieved [2]. Besides mechanical plaque removal by toothbrushing and interdental cleaning, a toothpaste may help to remove plaque and spread therapeutic ingredients, like fluorides and antibacterial agents, through the oral cavity. An effective oral antibacterial should have a broad spectrum of antibacterial activity, but at the same time it should not disturb the oral microbiome at 
health [3]. Moreover, it should be compatible with other toothpaste ingredients [4]. There are several ways by which antibacterial agents can influence a biofilm, like interference with bacterial co-aggregation mechanisms or by affecting bacterial viability [5].

The efficacy of an antibacterial agent depends not only on its antibacterial power but also on its substantivity. Due to its capability to bind to oral surfaces and subsequent slow release in bio-active concentrations, a substantive antibacterial agent remains active in the oral cavity for a prolonged period of time [6-8]. A wellknown example of a substantive antibacterial agent is chlorhexidine. Effects on bacterial viability in saliva of a $0.2 \%$ chlorhexidine rinse could be perceived up to $7 \mathrm{~h}$ post-use [9]. Also substantive effects of an amine fluoride/stannous fluoride mouthrinse and toothpaste [10] and a triclosancontaining toothpaste [6] on biofilm vitality have been observed, respectively 7 and $24 \mathrm{~h}$ after application. However, it was never assessed whether absorption of antibacterial agents in plaque could substantially contribute to the observed substantive effects in addition to their adsorption to oral surfaces.

Recently, research implied that an in vitro biofilm can absorb antimicrobials, followed by substantive release in bio-active concentrations [11]. This yields the question whether antibacterial agents can be absorbed in plaqueleft-behind after toothbrushing with an antibacterial toothpaste as well to inhibit further growth of oral biofilm. Absorption of fluoride in plaque-left-behind, a much smaller molecule than most antibacterial agents, has been studied and demonstrated to aid caries prevention [12, 13], but the absorption in plaque-left-behind and release of antibacterial agents from a toothpaste in a bio-active concentration has never been studied.

In the meantime [14], we have demonstrated that plaqueleft-behind after brushing can absorb oral antibacterial agents from mouthrinses. By mixing control plaques from volunteers using a control toothpaste (without antibacterial claims) with plaques from volunteers using an antibacterial mouthrinse in addition to brushing with the control toothpaste, it could be demonstrated that these plaques contained residual, bio-available antibacterials that were released over a 2-h time period in sufficiently high concentrations to kill bacteria in control plaque [14].

In the present study, it was hypothesized that plaque-leftbehind after brushing may also act as a reservoir for antibacterial toothpaste components and therewith contribute towards their substantivity. Therefore we compare the contributions of plaque and of saliva to the prolonged substantivity of three antibacterial toothpastes versus a control toothpaste, without antibacterial claims as well as possible changes in bacterial composition of plaque and saliva after the use of the different toothpastes.

\section{Materials and methods}

Toothpastes and recruitment of human volunteers

This unblinded clinical substantivity study was conducted in a parallel design and with exception of the Denaturing Gradient Gel Electropheresis (DGGE), entirely carried out by one professional dentist. For this study, four commercially purchased toothpastes, i.e., one control and three antibacterial toothpastes were selected, as listed in Table 1. The number of volunteers needed to complete the study was 74 (28 males, 46 females, age 19-29 years). They were all healthy dental and oral hygiene students recruited from the Center for Dentistry and Oral Hygiene at the University Medical Center Groningen. Six persons dropped out the study during use of the experimental toothpaste due to illness or not attending appointments. Each substantivity experiment consisted of two pairs of volunteers, one pair brushing for 2 weeks with the control toothpaste and the other pair brushing for 2 weeks with an antibacterial toothpaste and subsequently plaque and saliva samples were collected of all four volunteers (for more details see below). The order the volunteers came in was determinant for the allocation of the antibacterial toothpastes in alphabetical order over the volunteers (i.e., first Colgate $\operatorname{Total}^{\circledR}{ }^{\circledR} \times$, followed by Crest Pro Health ${ }^{\circledR} 5 \times$, and Zendium Classic ${ }^{\circledR}$ $5 \times$ ). The study was performed according to the guidelines of the Medical Ethics Committee of the University Medical Center Groningen, Groningen, The Netherlands, including the informed consent by the volunteers and the tenets of the Declaration of Helsinki.

\section{Experimental protocol}

The principle of the experimental set-up of the substantivity study for three antibacterial toothpastes versus one control toothpaste is schematically presented in Table 2 . One experiment comprised two pairs of volunteers, one pair brushing for 2 weeks with the control toothpaste (viz. the control group) and the other pair for 2 weeks with an antibacterial toothpaste (viz. the experimental group). Volunteers were paired to minimize inter-individual differences. Mechanical cleaning, consisting of brushing and interdental cleaning, was done twice a day according to the habitual routine of the volunteers. Note that the control pair from one experiment acted as an experimental pair in the experiment 2 weeks later. After 2 weeks of brushing with the control or antibacterial toothpaste, plaque and saliva samples from each individual volunteer were collected 6 or $12 \mathrm{~h}$ after brushing in the morning by the volunteers themselves in the dental clinic. Before collection volunteers were carefully instructed by a professional dentist how to collect plaque from the buccal, lingual, palatal, and interproximal sides of the 
Table 1 Toothpastes and their abbreviations as used in this study together with their main active components and manufacturer

\begin{tabular}{|c|c|c|c|}
\hline Toothpaste & Abbreviation & Main active components & Manufacturer \\
\hline Prodent Coolmint ${ }^{\circledR}$ & PC (control) & $\begin{array}{l}\text { Sodium fluoride } \\
\text { Sodium lauryl sulphate (SLS) }\end{array}$ & Sara Lee Household \& Bodycare, Exton, USA. \\
\hline Colgate Total ${ }^{\circledR}$ & $\mathrm{CT}$ & $\begin{array}{l}\text { Triclosan } \\
\text { Polyvinyl methylether maleic acid (PVM/MA) } \\
\text { Sodium fluoride } \\
\text { SLS }\end{array}$ & Colgate-Palmolive Company, Piscataway, USA \\
\hline Crest Pro Health ${ }^{\circledR}$ & $\mathrm{CPH}$ & $\begin{array}{l}\text { Stannous fluoride } \\
\text { Sodium hexametaphosphate } \\
\text { SLS }\end{array}$ & Procter \& Gamble, Cincinnati, USA \\
\hline Zendium Classic $\AA$ & $\mathrm{ZC}$ & $\begin{array}{l}\text { Sodium fluoride } \\
\text { Colostrum } \\
\text { Lactoperoxidase } \\
\text { Lysozyme } \\
\text { Glucose oxidase } \\
\text { Amyloglucosidase }\end{array}$ & Sara Lee Household \& Bodycare, Exton, USA \\
\hline
\end{tabular}

dentition with a sterile cotton swab stick and a dental instrument [14]. This professional dentist also controlled compliance with the instructions during collection. Plaque was suspended in $2 \mathrm{ml}$ sterile Reduced Transport Fluid [15]. In addition, approximately $2 \mathrm{ml}$ unstimulated saliva was collected. All samples were vortexed and sonicated for

Table 2 General principle of the allocation of the volunteers to the control and three experimental toothpaste groups together with the brushing and collection time for the pairs of volunteers

\begin{tabular}{|c|c|c|c|c|c|c|}
\hline \multirow[t]{3}{*}{ Week } & \multicolumn{4}{|l|}{ Volunteers brushing with } & \multirow{2}{*}{\multicolumn{2}{|c|}{$\begin{array}{l}\text { Plaque and saliva collection from } \\
\text { volunteers } \\
\text { Toothpaste }\end{array}$}} \\
\hline & \multirow{2}{*}{$\begin{array}{l}\text { Control toothpaste } \\
\text { Prodent Coolmint (PC) }\end{array}$} & \multicolumn{3}{|c|}{ Experimental toothpaste } & & \\
\hline & & Colgate Total (CT) & Crest Pro Health $(\mathrm{CPH})$ & Zendium Classic (ZC) & Control & Experimental \\
\hline 1 & $\mathrm{AB}$ & & & & & \\
\hline 2 & $\mathrm{CD}$ & & & & & \\
\hline 3 & $\mathrm{EF}$ & $\mathrm{AB}$ & & & $\mathrm{AB}$ & \\
\hline 4 & GH & $\mathrm{CD}$ & & & $\mathrm{CD}$ & \\
\hline 5 & IJ & $\mathrm{EF}$ & & & $\mathrm{EF}$ & $\mathrm{AB}$ \\
\hline 6 & KL & GH & & & GH & $\mathrm{CD}$ \\
\hline 7 & $\mathrm{MN}$ & $\mathrm{IJ}$ & & & IJ & $\mathrm{EF}$ \\
\hline 8 & OP & & KL & & KL & $\mathrm{GH}$ \\
\hline 9 & QR & & $\mathrm{MN}$ & & $\mathrm{MN}$ & IJ \\
\hline 10 & ST & & $\mathrm{OP}$ & & $\mathrm{OP}$ & KL \\
\hline 11 & UV & & QR & & QR & $\mathrm{MN}$ \\
\hline 12 & WX & & ST & & ST & OP \\
\hline 13 & $\mathrm{YZ}$ & & & UV & UV & QR \\
\hline 14 & $\mathrm{ab}$ & & & WX & WX & ST \\
\hline 15 & $\mathrm{~cd}$ & & & $\mathrm{YZ}$ & $\mathrm{YZ}$ & UV \\
\hline 16 & ef & & & $a b$ & $a b$ & WX \\
\hline 17 & gh & & & $\mathrm{cd}$ & $\mathrm{cd}$ & $\mathrm{YZ}$ \\
\hline 18 & & & & & ef & $\mathrm{ab}$ \\
\hline 19 & & & & & gh & $\mathrm{cd}$ \\
\hline
\end{tabular}

Each capital and small letter represents one volunteer 
$10 \mathrm{~s}$ at $30 \mathrm{~W}$ (Vibra Cell model 375, Sonics and Materials Inc., Danbury, CT, USA) in order to suspend bacterial clumps. Subsequently, both plaque and saliva samples of the individual volunteers in the control and experimental pairs were pooled. In total, four pooled samples were obtained in one experiment: a control $(\mathrm{Pc})$ and an experimental plaque sample (Pe) and a control $(\mathrm{Sc})$ and an experimental saliva sample (Se). These newly formed samples were studied with respect to their bacterial concentration and viability, immediately and $2 \mathrm{~h}$ after pooling of the pairs (for details, see below and Otten et al. [14]). For each antibacterial toothpaste, the experiment was done in fivefold, involving 5 pairs of volunteers per toothpaste (see Table 2) making a total of 20 volunteers.

In addition, control and experimental individual plaque samples from six volunteers were suspended after centrifugation in $0.5 \mathrm{ml}$ TE buffer $(10 \mathrm{mM}$ Tris- $\mathrm{HCl}, \mathrm{pH} 7.5,1 \mathrm{mM}$ EDTA) and were stored at $-20^{\circ} \mathrm{C}$ for analysis of compositional similarity.

\section{Analyses of plaque and saliva samples}

The bacterial compositions of the plaques after use of the control or antibacterial toothpastes were compared using DGGE. After thawing, $0.5 \mathrm{ml}$ plaque samples in TE buffer were centrifuged for $5 \mathrm{~min}$ at $13,000 \times \mathrm{g}$ washed and vortexed with $200 \mu \mathrm{l}$ TE. After DNA extraction, PCR was performed on 100 ng DNA with a T-gradient thermocycler. DGGE of PCR products generated with the F357GC/R518 primer set [16] was performed as described by Muyzer et al. [17]. The PCR products were applied on $8 \%(w / v)$ polyacrylamide gel in $0.5 \times$ TAE buffer $(20 \mathrm{mM}$ Tris acetate, $10 \mathrm{mM}$ sodium acetate, $0.5 \mathrm{mM}$ EDTA, $\mathrm{pH}$ 8.3). The denaturing gradient consisted of $30-80 \%$ denaturant (100\% denaturant equals $7 \mathrm{M}$ Urea and $37 \%$ formamide). A 10-ml stacking gel without denaturant was added on top. Electrophoresis was performed overnight at $120 \mathrm{~V}$ and $60^{\circ} \mathrm{C}$. Gels were stained with silver nitrate [18]. DGGE gel images were converted and transferred into a microbial database with GelCompar II, version 6.1 (Applied Maths). The similarities in bacterial composition between control plaques and plaques collected after using an antibacterial toothpaste were analyzed using a ban based similarity coefficient (Dice). The clustering algorithm to calculate the dendograms was a non-weighted pair group method with arithmetic averages (UPGMA) [19].

The bacterial concentrations in pooled control and experimental plaque and saliva samples $(\mathrm{Pc}, \mathrm{Pe}, \mathrm{Sc}$, and $\mathrm{Se})$ were determined using a Bürker-Türk counting chamber and a phase contrast microscope (Olympus BH-2, Japan). Bacterial viability was determined by staining $20 \mu \mathrm{l}$ of a sample with $80 \mu \mathrm{l}$ LIVE/DEAD stain (BacLight $^{\mathrm{TM}}$, Molecular Probes Europe BV) to distinguish dead and live bacteria.
Images were taken with a fluorescent microscope (LEICA DM4000 B, Leica Microsystems Heidelberg GmbH, Heidelberg, Germany). At least three images of each sample were randomly taken, involving a minimum of 100 bacteria. Subsequently, the number of dead and live bacteria was counted and the viability per sample was expressed as a percentage live bacteria $(\% L)$. For each toothpaste evaluated, experiments were performed in fivefold, involving 20 volunteers.

If plaque acts as a reservoir for antibacterials, these should be able to kill bacteria in unexposed plaque $(\mathrm{Pc})$. In order to evaluate the antibacterial activity in the Pe sample, a novel mixture technique as described by Otten et al. [14] was used. In short, a 1:1 mixture of the Pc and Pe samples was made, denoted as $\mathrm{PcPe}$ of which the bacterial viability was assessed $2 \mathrm{~h}$ after combining. A comparable mixture, denoted as PcSe, was made to evaluate the antibacterial activity in saliva $2 \mathrm{~h}$ after combining to allow sufficient time for antibacterial action on the untreated bacteria in the mixtures. After $2 \mathrm{~h}$, the bacterial viabilities of the mixtures were experimentally determined in combined plaque and plaque-saliva samples and compared with theoretically expected viabilities of the mixtures at $t=0$. Since both $\mathrm{Pe}$ and Se exert immediate antibacterial effects on Pc if any, theoretically expected viabilities of both $\mathrm{PcPe}$ and PcSe were calculated based on the viabilities of $\mathrm{Pc}, \mathrm{Pe}$, and $\mathrm{Se}$ at $t=0$ using the following equations

$\% L_{\mathrm{PcPe}}=\frac{\left(\% L_{\mathrm{Pc}} \times C_{\mathrm{Pc}}\right)+\left(\% L_{\mathrm{Pe}} \times C_{\mathrm{Pe}}\right)}{C_{\mathrm{Pc}}+C_{\mathrm{Pe}}}$

$\% L_{\mathrm{PcSe}}=\frac{\left(\% L_{\mathrm{Pc}} \times C_{\mathrm{Pc}}\right)+\left(\% L_{\mathrm{Se}} \times C_{\mathrm{Se}}\right)}{C_{\mathrm{Pc}}+C_{\mathrm{Se}}}$

where $\% L_{\mathrm{Pc}}, \% L_{\mathrm{Pe}}, \% L_{\mathrm{Se}}, C_{\mathrm{Pc}}, C_{\mathrm{Pe}}$, and $C_{\mathrm{Se}}$ represent the experimental viabilities and bacterial concentrations of $\mathrm{Pc}$, $\mathrm{Pe}$, and Se.

Experimental viabilities, lower than theoretically expected, are an indication that the experimental plaque or saliva still contained residual antibacterial activity, 6 or $12 \mathrm{~h}$ after the last brushing.

\section{Statistical analysis}

The data were analyzed using one way ANOVA (analysis of variance) to indicate significant differences between bacterial viabilities and concentrations of plaque and saliva samples after brushing with the different toothpastes. The Student's $t$ test was used for statistical comparison between the control and antibacterial toothpastes. Values of $p<0.05$ were considered to indicate statistically significant differences. 


\section{Results}

The bacterial composition of the experimental plaques was influenced by the toothpaste used and the largest dissimilarities in bacterial composition with respect to the control paste were observed $6 \mathrm{~h}$ after use of $\mathrm{CPH}$, as can be seen in Table 3. Interestingly, the similarity after use of $\mathrm{CPH}$ increased between 6 and $12 \mathrm{~h}$ after last use, while for CT the similarity decreased over time.

In general, plaques collected after the use of $\mathrm{CT}$ and $\mathrm{CPH}$ had lower viabilities than the control plaque, while plaques collected after the use of ZC showed similar viability as the control plaque (Table 4). There was no statistically significant difference between viabilities of plaques collected 6 or $12 \mathrm{~h}$ after brushing with the control paste, $\mathrm{CT}$ or $\mathrm{CPH}$, but plaques collected $12 \mathrm{~h}$ after brushing with $\mathrm{ZC}$ were more viable than when collected $6 \mathrm{~h}$ after brushing $(p<0.05)$. Moreover, the concentration of bacteria in plaque decreased significantly between 6 and $12 \mathrm{~h}$ after brushing with $\mathrm{ZC}$ and PC $(p<0.05)$. The differences in viability assessed immediately or $2 \mathrm{~h}$ after collection were not statistically significant.

Only bacterial viabilities in saliva samples (Table 4) collected $12 \mathrm{~h}$ after brushing with CT (41\% viability) were significantly different $(p<0.05)$ compared to the control toothpaste ( $56 \%$ viability). Similarly, the bacterial viabilities of saliva collected $12 \mathrm{~h}$ after brushing with ZC (66\% viability) were significantly different $(p<0.05)$ from saliva collected $6 \mathrm{~h}$ after brushing with ZC (50\% viability). Bacterial concentrations were not significantly different across the different saliva samples, with the exception of saliva collected $12 \mathrm{~h}$ after brushing with $\mathrm{CPH}$, containing significantly $(p<0.05)$ less bacteria than the control saliva samples.

The experimental and theoretically expected viabilities of combined control and experimental plaques are compared in Table 5. For CT and ZC, experimental viabilities are smaller, respectively larger than theoretically expected, but these effects are not statistically significant. Experimental viabilities are significantly smaller $(p<0.05)$ than theoretically

Table 3 Similarities based on DGGE analysis in bacterial composition between control plaques, obtained during use of Prodent Coolmint ${ }^{\circledR}$ and experimental plaques, collected during the use of an antibacterial toothpaste

\begin{tabular}{|c|c|c|c|}
\hline \multirow{2}{*}{$\begin{array}{l}\text { Collection } \\
\text { time (h) }\end{array}$} & \multicolumn{3}{|c|}{ Similarity (\%) } \\
\hline & $\begin{array}{l}\text { Colgate } \\
\text { Total }{ }^{\circledR}(\mathrm{CT})\end{array}$ & $\begin{array}{l}\text { Crest Pro } \\
\text { Health }{ }^{\circledR}(\mathrm{CPH})\end{array}$ & $\begin{array}{l}\text { Zendium } \\
\text { Classic }{ }^{\circledR}(\mathrm{ZC})\end{array}$ \\
\hline 6 & $77 \pm 7$ & $60 \pm 14$ & $75 \pm 7$ \\
\hline 12 & $67 \pm 6$ & $67 \pm 15$ & $71 \pm 8$ \\
\hline
\end{tabular}

Volunteers $(n=6)$ brushed for 2 weeks with a control toothpaste, followed by 2 weeks of brushing with an antibacterial toothpaste. Values are presented as averages \pm standard deviations for plaques collected 6 and $12 \mathrm{~h}$ after the last brushing

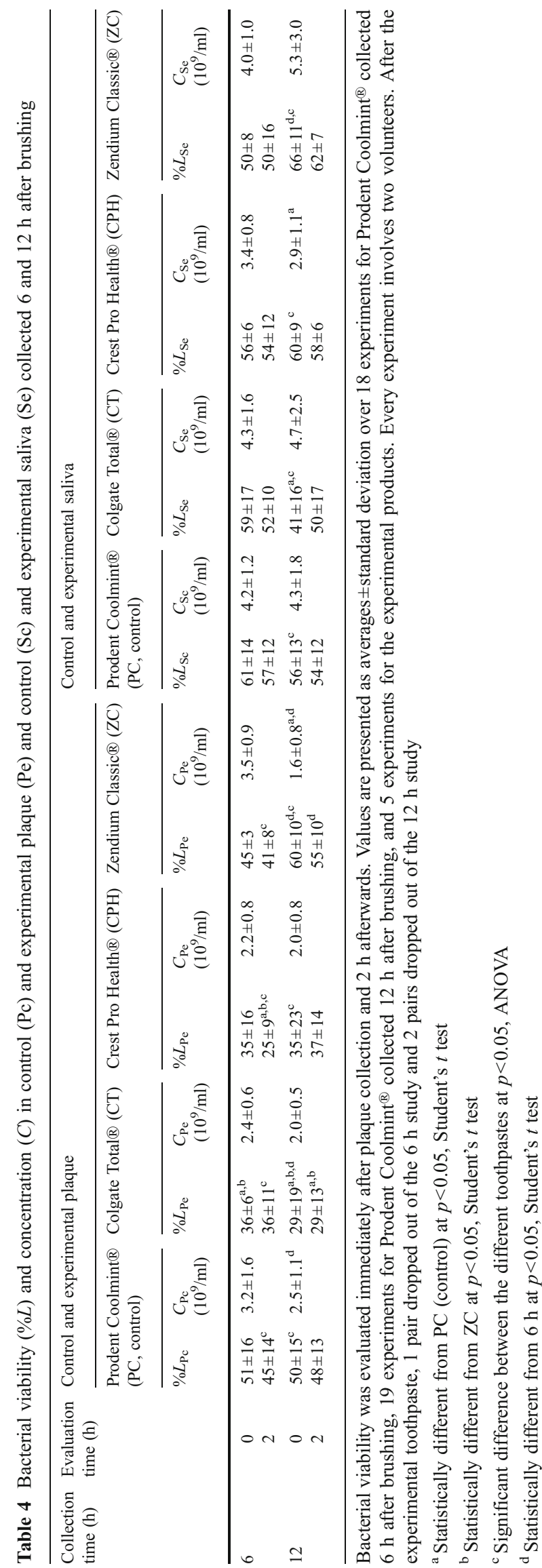


Table 5 Experimentally measured and theoretically expected bacterial viabilities of combined control and experimental plaques (PcPe) and control plaque and experimental saliva samples (PcSe) collected 6 or $12 \mathrm{~h}$ after brushing

\begin{tabular}{|c|c|c|c|c|c|c|c|c|}
\hline \multirow{3}{*}{$\begin{array}{l}\text { Control plaque combined } \\
\text { with } \mathrm{Pe} \text { and } \mathrm{Sc} \text {, using }\end{array}$} & \multicolumn{4}{|l|}{$\% L_{\mathrm{PcPe}}$} & \multicolumn{4}{|l|}{$\% L_{\mathrm{PcSe}}$} \\
\hline & \multicolumn{2}{|c|}{$6 \mathrm{~h}$ after collection } & \multicolumn{2}{|c|}{$12 \mathrm{~h}$ after collection } & \multicolumn{2}{|c|}{$6 \mathrm{~h}$ after collection } & \multicolumn{2}{|c|}{$12 \mathrm{~h}$ after collection } \\
\hline & Experimental & Expected & Experimental & Expected & Experimental & Expected & Experimental & Expected \\
\hline Colgate Total ${ }^{\circledR}(\mathrm{CT})$ & $36 \pm 8$ & $44 \pm 17$ & $31 \pm 21$ & $37 \pm 11$ & $55 \pm 12$ & $53 \pm 10$ & $43 \pm 7$ & $47 \pm 14$ \\
\hline Crest Pro Health ${ }^{\circledR}(\mathrm{CPH})$ & $22 \pm 9^{\mathrm{a}}$ & $35 \pm 5$ & $31 \pm 5^{\mathrm{a}}$ & $46 \pm 6$ & $50 \pm 12$ & $51 \pm 7$ & $56 \pm 7$ & $56 \pm 3$ \\
\hline Zendium Classic ${ }^{\circledR}$ (ZC) & $42 \pm 9$ & $38 \pm 7$ & $57 \pm 13$ & $54 \pm 8$ & $46 \pm 6$ & $42 \pm 11$ & $65 \pm 12$ & $60 \pm 7$ \\
\hline
\end{tabular}

Values are presented as average percentage live bacteria \pm standard deviation over 5 experiments, involving 20 volunteers per comparison

${ }^{\text {a }}$ Statistically lower than theoretically expected values at $p<0.05$, Student's $t$ test

expected ones for $\mathrm{CPH}$, indicating residual antibacterial activity in plaques left behind 6 and $12 \mathrm{~h}$ after brushing with $\mathrm{CPH}$. Combining control plaques with experimental saliva's (Table 5) did not yield any effect on bacterial viability, indicating that there is no residual antibacterial activity due to toothpaste components left in saliva 6 or $12 \mathrm{~h}$ after brushing.

\section{Discussion}

Our hypothesis that plaque-left-behind after brushing may act as a reservoir for antibacterial toothpaste components and therewith contribute towards their substantivity is confirmed by the present results for a stannous fluoride containing antibacterial toothpaste $(\mathrm{CPH})$. Both antibacterial toothpastes, $\mathrm{CT}$ and $\mathrm{CPH}$, reduced bacterial viability in plaque up to $12 \mathrm{~h}$ after brushing, but only plaque-leftbehind after brushing with $\mathrm{CPH}$ still contained significant residual antibacterial activity up to $12 \mathrm{~h}$ after brushing to cause prolonged killing of bacteria in unexposed plaque. Whether or not this reservoir function of the plaque-leftbehind will contribute to an clinically significant reduction in caries and gingivitis remains to be determined, however.

The effects of plaque-left-behind after brushing with an antibacterial toothpaste have been demonstrated by comparison with a control toothpaste (see Table 4). The control toothpaste chosen was a regular sodium fluoride-SLS containing paste, without any antibacterial claims, similar to most other sodium fluoride-SLS containing pastes. This is not withstanding the fact that both fluoride and SLS may have antibacterial efficacy $[8,20]$. Note that the viabilities of plaque samples collected after use of the control paste are comparable with the ones measured in vivo after the use of Crest Regular ${ }^{\circledR}$, another sodium fluoride-SLS containing toothpaste without antibacterial claims [21]. Viabilities of plaque samples obtained after brushing with triclosan/ copolymer containing $\mathrm{CT}$ and stannous fluoride/ hexametaphosphate containing $\mathrm{CPH}$ toothpastes, however, show reduced viabilities with respect to the control, in line with their known antibacterial efficacies in vivo and in vitro [6, 21-23]. The differences in compositional similarity of the different experimental plaques with respect to the control plaque suggest that the antibacterial components in the different pastes act on different strains and species.

Triclosan in toothpastes is often used in combination with a copolymer PVM/MA (polyvinyl methyl ether/maleic acid) $[6,24-25]$ and increases the permeability of the bacterial cell membrane, causing leakage of the cellular content, which finally leads to cell death [8]. Stannous fluoride $\left(\mathrm{SnF}_{2}\right)$ is recently used in toothpastes in combination with sodium hexametaphosphate to provide antiplaque $[3,26]$ and antigingivitis activity [3,24]. Conflicting reports exists about the antibacterial efficacy of the enzyme containing toothpaste ZC, included in this study. Enzymes, like amyloglucosidase and glucose oxidase, are added to ZC toothpaste to enhance the host defense mechanisms [20]. Another ingredient added, supporting the host defense, is colostrum [27]. Whereas Tenovuo [27] concluded in a literature review that adding enzymes to a toothpaste improves the antibacterial capacity of saliva, in vivo the use of an enzyme containing toothpaste was unable to achieve differences in plaque and gingivitis scores as compared to a control toothpaste [7, 28]. Also in our study, we did not find an effect of the enzyme containing toothpaste on bacterial viabilities of plaques collected 6 or $12 \mathrm{~h}$ after brushing.

Despite the fact that both triclosan/copolymer containing CT and stannous fluoride/hexametaphosphate containing $\mathrm{CPH}$ toothpastes show reduced viabilities in plaque-left-behind after brushing, only plaques obtained after use of a stannous fluoride/ hexamethaphosphate containing toothpaste still had sufficient residual antibacterial activity to cause significant bacterial killing (see Table 5). A triclosan/copolymer containing paste did not show such a contribution toward substantivity by plaqueleft-behind in a statistically significant way, which probably suggests that the larger triclosan/copolymer molecules are 
not absorbed into plaque to the same extent as relatively small stannous fluoride molecules.

As might be expected from the lack of a direct effect of antibacterial agents on bacterial viability in saliva (Table 4), no contribution of saliva toward the prolonged substantivity of any of the antibacterial agents as delivered during toothbrushing was found (Table 5). Besides the antibacterial agents added to toothpastes, saliva exerts a continuous antibacterial effect [29]. The prolonged substantivity of chlorhexidine, accepted as the most effective oral antibacterial $[8,20]$, is generally attributed to weak adsorption followed by slow desorption to and from oral soft tissue surfaces to yield a prolonged effective antibacterial concentration in saliva [9]. Evidently, neither stannous fluoride nor the triclosan/copolymer combination adsorbs and/or desorbs in effective concentrations from the oral soft tissues into saliva.

In conclusion, plaque-left-behind after mechanical cleaning may contribute to the substantive action of an antibacterial toothpaste. Therewith, this study constitutes a pledge for the use of antibacterial toothpastes, since antibacterials can be absorbed in plaque-left-behind. The importance of antibacterials absorbed in plaque-left-behind is even amplified, when it is realized that plaque is predominantly left behind in places where its removal and effective killing matter most, i.e., in retention sites like fissures, interproximal spaces, gingival margins, or around orthodontic appliances that are hard to clean mechanically [2]. In this respect, it is worth mentioning that these conclusions are based on results obtained in a group of dental and oral hygiene students, who mostly have better skills to remove plaque than the general public. In the general public, the amount of plaque-left-behind after brushing can be expected to be larger than in the current study, which may yield an even more pronounced contribution of plaque-left-behind toward the substantive action of antibacterial toothpaste components.

Acknowledgments The authors gratefully thank all the volunteers who participated in this study. The authors would like to thank J. Atema-Smit and G.I. Geertsema-Doornbusch for their assistance in the technical procedures.

Conflict of interest The authors declare that they have no conflict of interest.

Open Access This article is distributed under the terms of the Creative Commons Attribution Noncommercial License which permits any noncommercial use, distribution, and reproduction in any medium, provided the original author(s) and source are credited.

\section{References}

1. Cugini M, Warren PR (2006) The Oral-B cross action manual toothbrush: a 5-year literature review. J Can Dent Assoc 72:323a-323k
2. Van der Weijden FA, Echevarria JJ, Sanz M, Lindhe J (2008) Mechanical supragingival plaque control. In: Lindhe J, Lang NP, Karring T (eds) Clinical periodontology and implant dentistry, 5th edn. Blackwell Munskgaard, Copenhagen, pp 705-733

3. Paraskevas S, Van der Weijden GA (2006) A review of the effects of stannous fluoride on gingivitis. J Clin Periodontol 33:1-13

4. Gaffar A, Afflitto J, Nabi N (1997) Chemical agents for the control of plaque and plaque microflora: an overview. Eur J Oral Sci 105:502-507

5. Baehni PC, Takeuchi Y (2003) Anti-plaque agents in the prevention of biofilm-associated oral diseases. Oral Dis 9(Suppl 1):23-29

6. Arweiler NB, Auschill TM, Reich E, Netuschil L (2002) Substantivity of toothpaste slurries and their effect on reestablishment of the dental biofilm. J Clin Periodontol 29:615-621

7. Eley BM (1999) Antibacterial agents in the control of supragingival plaque - a review. Br Dent J 186:286-296

8. Scheie AA (2003) The role of antimicrobials. In: Fejerskov O, Kidd E (eds) Dental caries, the disease and its clinical management, 1st edn. Blackwell Munksgaard, Oxford, pp 179-188

9. Cousido MC, Tomas CI, Garcia-Caballero L, Limeres J, Alvarez M, Diz P (2010) In vivo substantivity of $0.12 \%$ and $0.2 \%$ chlorhexidine mouthrinses on salivary bacteria. Clin Oral Investig 14:397-402

10. Weiland B, Netuschil L, Hoffman T, Lorenz K (2008) Substantivity of amine fluoride/stannous fluoride following different modes of application: A randomized, investigator-blind, placebo-controlled trial. Acta Odontol Scand 66:307-313

11. Verkaik MJ, Busscher HJ, Jager D, Slomp AM, Abbas F, Van der Mei HC (2011) Efficacy of natural antimicrobials in toothpaste formulations against oral biofilms in vitro. J Dent 39:218-224

12. Sjogren K, Birkhed D, Rangmar S, Reinhold AC (1996) Fluoride in the interdental area after two different post-brushing water rinsing procedures. Caries Res 30:194-199

13. Nordström A, Birkhed D (2009) Fluoride retention in proximal plaque and saliva using two NaF dentifrices containing 5,000 and 1,450 ppm F with and without water rinsing. Careis Res 43:64-69

14. Otten MPT, Busscher HJ, Van der Mei HC, Abbas F, Van Hoogmoed CG (2010) Retention of antimicrobial activity in plaque and saliva following mouthrinse use in vivo. Caries Res 44:459-464

15. Syed SA, Loesche WJ (1972) Survival of human dental plaque flora in various transport media. Appl Microbiol 24:638-644

16. Di Cagno R, Rizzello CG, Gagliardi F, Ricciuti P, Ndagijimana M, Francavilla R, Guerzoni ME, Crecchio C, Gobbetti M, De Angelis M (2009) Different fecal microbiotas and volatile organic compounds in treated and untreated children with celiac disease. Appl Environ Microbiol 75:3963-3971

17. Muyzer G, De Waal EC, Uitterlinden AG (1993) Profiling of complex microbial populations by denaturing gradient gel electrophoresis analysis of polymerase chain reaction-amplified genes coding for 16S rRNA. Appl Environ Microbiol 59:695700

18. Zijnge V, Welling GW, Degener JE, Van Winkelhoff AJ, Abbas F, Harmsen HJM (2006) Denaturing gradient gel electrophoresis as a diagnostic tool in periodontal microbiology. J Clin Microbiol 44:3628-3633

19. Signoretto C, Bianchi F, Burlacchini G, Sivieri F, Spratt D, Canepari P (2010) Drinking habits are associated with changes in the dental plaque microbial community. J Clin Microbiol 48:347-356

20. Addy M (1997) Antiseptics in periodontal therapy. In: Lindhe J, Karring T, Lang NP (eds) Clinical periodontology and implant dentistry, 3rd edn. Munksgaard, Copenhagen, pp 461-482

21. Van der Mei HC, White DJ, Atema-Smit J, Van de Belt-Gritter E, Busscher HJ (2006) A method to study sustained antimicrobial activity of rinse and dentifrice components on biofilm viability in vivo. J Clin Periodontol 33:14-20 
22. Addy M, Jenkins S, Newcombe R (1990) The effect of triclosan, stannous fluoride and chlorhexidine products on: (I) plaque regrowth over a 4-day period. J Clin Periodontol 17:693-697

23. Ramji N, Baig A, He T, Lawless MA, Saletta L, SuszcynskyMeister E, Coggan J (2005) Sustained antibacterial actions of a new stabilized stannous fluoride dentifrice containing sodium hexametaphosphate. Compend Contin Educ Dent 26:19-28

24. Gunsolley JC (2006) A meta-analysis of six-month studies of antiplaque and antigingivitis agents. J Am Dent Assoc 137:16491657

25. Fine DH, Furgang D, Markowitz K, Sreenivasan PK, Klimpel K, De Vizio W (2006) The antimicrobial effect of a triclosan/copolymer dentifrice on oral microorganisms in vivo. J Am Dent Assoc 137:1406-1413
26. White DJ, Kozak KM, Gibb R, Dunavent J, Klukowska M, Sagel PA (2006) A 24-hour dental plaque prevention study with a stannous fluoride dentifrice containing hexametaphosphate. J Contemp Dent Pract 7:1-11

27. Tenevuo J (2002) Clinical applications of antimicrobial host proteins lactoperoxidase, lysozyme and lactoferrin in xerostomia: efficacy and safety. Oral Dis 8:23-29

28. Moran J, Addy M, Newcombe R (1989) Comparison of the effect of toothpastes containing enzymes or antibacterial compounds with a conventional fluoride toothpaste on the development of plaque and gingivitis. J Clin Periodontol 16:295-299

29. Nauntofte B, Tenevuo JO, Lagerlof F (2003) Secretion and composition of saliva. In: Fejerskov O, Kidd E (eds) Dental caries, the disease and its clinical management, 1st edn. Blackwell Munksgaard, Oxford, pp 7-27 